\title{
THE INFLUENCE OF MINIMUM INVESTMENT CAPITAL, RISK PERCEPTION ON STUDENTS INVESTMENT IN INDONESIA CAPITAL MARKET
}

\author{
Titin Eka Ardiana ${ }^{1)}$, La Ode Sugianto ${ }^{2)}$, Siti Chamidah ${ }^{3)}$ \\ ${ }^{1}$ Faculty of Economics Muhammadiyah Ponorogo \\ Email: titineka31@gmail.com \\ ${ }^{2}$ Faculty of Economics Muhammadiyah Ponorogo \\ Email: laodesugianto45@gmail.com \\ ${ }^{3}$ Faculty of Economics Muhammadiyah Ponorogo \\ Email: siti.chanidah71@gmail.com
}

\begin{abstract}
This research aims to assess the minimum investment capital to start investing, and minimize the risk of loss and business instinct to analyze what effects are good to buy and of course will be profitable in investing in the capital market. The approach used in this research is quantitative explanative research. In this study, there are two kinds of variables used, namely the dependent variable and the independent variable. The dependent variable used for this study is student investment interest in the capital market, while the independent variable used in this study consists of minimum investment capital $\left(X_{1}\right)$ and risk perception $\left(X_{2}\right)$. The data collection technique in this study is to use primary data, namely a questionnaire. The analytical method used in this study is to use multiple linear regression analysis using calculations through SPSS version 20. The results show that there is a positive and significant effect of minimal investment capital and risk perception on student investment interest simultaneously at the Faculty of Economics, University of Muhammadiyah Ponorogo. The contribution of the two variables contributed $44.3 \%$ and the remaining $55.7 \%$ was influenced by other variables not examined in the study.
\end{abstract}

Keywords: Minimum Investment Capital, Risk Perception, and Investment Interest

\section{Introduction}

The capital market currently plays a strategic role in the Indonesian economy. The active role of capital market institutions is indispensable in building the Indonesian economy. The capital market plays a role as a means of the financial sector outside the banking sector that provides funds for the business world through the sale of shares, bonds and derivatives. Thus the main function of the capital market is a means or vehicle for capital formation and fund accumulation for financing a company (Septyanto, 2013).

The growth in the number of investors in the capital market is expanding in Indonesia. According to Rochmi (beritagar.id, 2018) in terms of demography, the growth of millennial generation investors or the young generation aged 17-25 years has experienced significant growth, namely their number reaches $30 \%$. This is due to the support of the Indonesia Stock Exchange, which has collaborated with academics at various universities in Indonesia to provide the Indonesia Stock Exchange Investment Gallery. Until now, the IDX has recorded 410 Investment Galleries throughout Indonesia. The IDX Investment Gallery is a means of 
introducing the capital market from an early age to the world of academia to increase student literacy towards the capital market (www.idx.go.id).

With the Investment Gallery in Higher Education, the number of new investors among students has also increased even though they do not have fixed income, but the interest of students to invest is quite high (Pajar, 2017). In accordance with the Theory of Reasoned Action according to Ajzen (Susilowati, 2017) that human behavior is influenced by intention or interest which will ultimately lead to a perception of an action.

To attract students to become investors in the capital market, the Indonesia Stock Exchange (IDX) and the Financial Attorney Authority (OJK) provide convenience for investors, namely by the presence of online securities trading facilities known as online trading and minimal investment capital issued by prospective investors are getting cheaper (Wulandari et al, 2017).

As a capital market manager, the Indonesia Stock Exchange (IDX) issued a regulation on changes to trading units and price fractions as stated in the Decree Number: Kep-00071 / BEI / 11-2013, where the trading unit of shares in 1 lot from 500 shares becomes 100 shares with a minimum price of shares traded on the IDX is IDR 50 per share. In some securities at this time, the initial funds that must be deposited to create an account are only IDR 100,000, so that this convenience is expected to provide motivation and interest in investing in the capital market (Pajar, 2017).

Students' interest in investing in the capital market can be influenced by several factors, such as perceptions of risk and minimal investment capital. Each person has different perceptions of risk, even students who are equipped with knowledge of the capital market also have different perceptions of risk. Some students dare to take risks, and some students do not dare to take risks. Investing in the capital market cannot be separated from risks. The higher the risk you dare to take, the higher the chances of the benefits you will get. Malik (2017) states that the higher the risk, the more investors' interest in investing.

The purpose of establishing the Indonesia Stock Exchange Investment Gallery at the University location is to get closer to knowledge of the capital market among academics, increase investment knowledge and become a means of information for students who are interested in becoming investors. The Faculty of Economics at Muhammadiyah Ponorogo University in collaboration with the Indonesia Stock Exchange (IDX). The Indonesia Stock Exchange Investment Gallery is actively conducting Capital Market Training for students and is expected to be able to attract students to become potential investors (Merawati, 2015).

IDX Investment Gallery - Muhammadiyah University Ponorogo has started to make it easier for potential investors, for example by implementing an online trading system (trading stocks via the internet) or making the minimum deposit that must be issued by potential investors easier. For students and / or the general public in general, it is given convenience, the minimum deposit for investment through the IDX Investment Gallery - Muhammadiyah University of Ponorogo is only one hundred thousand rupiah. From a student perspective, there are many factors that influence student interest in investing in the capital market. Thus, based on the description of the background above, the researcher is interested in writing the title "The Influence of Minimal Investment Capital, Risk Perception on Student Investment Interest in the Indonesian Capital Market". 


\section{Theoritical Review And Hypothesis Development}

Investment Interesting the Indonesian Capital Market

\section{1) Theory Of Planned Behavior / Theory of Reasoned Action}

The theory that can explain the relationship between attitudes and one's behavior is the Theory of Planned Behavior which is the development of the Theory of Reasoned Action which according to Ajzen (Pajar, 2017) where a person's behavior is determined by an intention which is a function of behavior on subjective norm behavior. This intention is determined by 3 things, namely behavior, subjective norms and behavior control.

According to Raditya (2014) Theory of Planned Behavior states that of the three points, behavior is the main point for predicting a behavior. Measuring behavior requires knowing a person's beliefs and attitudes. Behavioral control refers to a person's perception of their ability to behave. Finally, subjective norms will show how a person behaves. If you want to predict someone's intention, you must know the three predictors, because with that you will be able to deduce a person's intention.

\section{2) Investment Interest}

Interest is influenced by several factors which according to (Susilowati, 2017) are factors that come from oneself, do not have a clear purpose, whether or not there is a benefit to something being learned for individuals. The relation with student investment interest, if the student is already interested in investing, he will look for information about investment and try to carry out investment activities such as buying stocks, bonds or mutual funds.

Investment interest is the desire to find out about the type of investment starting from the advantages, weaknesses, investment performance and so on (Kusmawati, 2011). Another characteristic of people who are interested in investing is to find out more extensive information, study it and then put it into practice.

\section{Capital Market}

\section{1) Definition of Capital Market}

The Indonesian capital market, known as the Indonesia Stock Exchange (IDX), is a combination of two stock exchanges, namely the Jakarta Stock Exchange (BEJ) and the Surabaya Stock Exchange (SSE) on October 30, 2007 (Pajar, 2017). The term capital market comes from the words market and capital. According to Sunariyah (2011) the definition of a capital market in general is an organized financial system, including commercial banks and all intermediary institutions in the financial sector, as well as all marketable securities in circulation. Meanwhile, in a narrow sense, the capital market is a market that is prepared to trade stocks, bonds, other types of securities using the services of securities brokers.

According to Martalena and Malinda (2011), theoretically the capital market (capital market) is a market for various long-term financial instruments that can be traded, both bonds (bonds), equities (stocks), mutual funds, derivative instruments and other instruments. Meanwhile, according to Law No. 8 of 1995, it states that the capital market is an activity related to public offerings and securities trading, companies related to the securities they issue, as well as institutions and professions related to the securities they issue.

\section{2) Minimum Investment Capital}

Currently, the IDX (Indonesia Stock Exchange) has penetrated students to become investors in the capital market. BEI (Indonesia Stock Exchange) has collaborated with various 
universities to provide an Investment Gallery. With the Investment Gallery in every university, it will make it easier for students to increase literacy in the world of capital markets and learn to invest. Several securities companies are now starting to see students as promising marketing targets, where in the future students will be someone who is earning and capable makes a high contribution to the sustainability of the capital market in Indonesia (Marleni, 2017).

Students can choose investment instruments such as mutual funds and stocks. Currently, many securities companies have implemented a minimum investment capital of IDR 100,000 to start investing in the capital market, making it easier for potential investors, including students (Wulandari et al., 2017). To start buying shares, every investor must open an account in securities or often referred to as a broker, as an official institution that becomes an intermediary between one investor and another. With this minimum investment capital, it is hoped that it can attract investment students to start trading in the capital market.

\section{Perceived Risk}

According to Jogiyanto (2010) return and risk are two separate things, but return and risk have a positive relationship, namely the greater the risk borne, the greater the return that will be compensated. The definition of risk according to (Fahmi, 2015) is defined as a form of uncertainty about a situation that will occur in the future as a result of decisions made based on various current considerations.

\section{Hypothesis}

The development of the hypotheses developed in this study are as follows:

1) The Effect of Initial Investment Capital on Student Investment Interest in the Indonesian Capital Market

Ho1: Minimum investment capital has no effect on the investment interest of students in the Indonesian Capital Market

Ha1: Minimum investment capital affects students' investment interest in the Indonesian Capital Market

2) The effect of risk perception on student investment interest in the Indonesian capital market.

Ho2: Perception of risk has no effect on student investment interest in the Indonesian Capital Market

Ha2: Perception of risk affects student investment interest in the Indonesian Capital Market

3) The effect of minimal investment capital, risk perception on student investment interest in the Indonesian Capital Market

Ho3: Minimum investment capital and risk perception do not simultaneously influence student investment interest in the Indonesian Capital Market

Ha3: Minimum investment capital and risk perception have a simultaneous effect on student investment interest in the Indonesian Capital Market

\section{Research Methods}

\section{Research population}

The population in this research were all students of the Faculty of Economics, University of Muhammadiyah Ponorogo, batch 2015 and 2016, totaling 924 students. 


\section{Research Samples}

The sample is part of the number and characteristics of the population (Sugiyono, 2017). The sampling technique used in this study was the simple random sampling method, in which the sampling of members of the population was done randomly with the same percentage for each department. The smples were taken by using the Slovin quantity calculation formula (Santoso, 2015). From the Slovin formula, a total sample of 280 students will be sampled in this study.

\section{Operational and Measurement Variabel Definition}

a. Minimum Investment Capital $\left(\mathrm{X}_{1}\right)$

This minimum investment capital is the initial capital needed to open an initial account in the capital market before carrying out trading activities (Raditya, 2014). For academics or students, the minimum investment amount for securities has reached the level of hundreds of thousands, namely a minimum of IDR 100,000 (www.idx.co.id). The indicators used to measure minimum investment capital refer to Susilowati's (2017) research, namely:

- Establishment of initial capital

- Estimated funds for investment

- Investment returns

b. Perceived Risk $\left(X_{2}\right)$

Perceptions of risk play an important role in human behavior, especially in relation to decision making in uncertain situations. (Rosyidah, 2013). Investors experience risks when investors do not know with certainty the results of their investments (Malik, 2017). Luh Komang (Pajar, 2017) explains that the perception of risk is one of the factors that most influences investment interest. The indicators used to measure risk preference refer to Pajar's (2017) research and Winantyo's (2017) research, namely:

- The level of risk helps minimize losses.

- The level of risk is proportional to the benefits that will be obtained.

- The high level of risk is an interesting challenge.

c. Investment Interest Variable (Y)

The dependent variable used for this study is the investment interest of students at the Faculty of Economics, Muhammadiyah University of Ponorogo in the Capital Market. Investment interest is the tendency of someone who stays in the subject to feel happy and interested in a certain field or thing and feel happy being involved in that field (Tandio, 2016). The indicators used to measure this interest refer to research (Pajar, 2017) which includes:

- Desire: The desire to find out about the type of investment.

- Passion: to take the time to learn more about investing by attending investment training and seminars.

- Confidence to try to invest.

\section{Analysis Technique}

The method of analysis used in this study is to use multiple linear regression analysis using calculations through SPSS version 22. Multiple linear regression analysis is used to determine the effect of the independent variable and the dependent variable. It is said to be significant if the statistical test value is in a critical area (Ho is rejected) and it is said to be 
insignificant if the statistical test is in Ho is accepted (Sugiyono, 2017). In general, the multiple linear regression equation model is as follows:

$\mathrm{Y}=\mathrm{a}+\mathrm{b}_{1} \mathrm{X}_{1}+\mathrm{b}_{2} \mathrm{X}_{2}$

Information:

$\mathrm{Y} \quad=$ Investment Interest

$\mathrm{a} \quad=$ Constant

$\mathrm{X}_{1} \quad=$ Minimum investment capital

$\mathrm{X}_{2} \quad=$ Perceived risk

$\mathrm{b} 1, \mathrm{~b}_{2}=$ Regression Coefficient

\section{Hypothesis testing}

$\mathrm{t}$ statistical test is used to show how far the influence of one independent variable individually is in explaining the variation of the dependent variable (Ghozali, 2011). The level of significance used is $5 \%$ or $(\alpha)=0.05$.

\section{Results And Discussion}

Multiple Linear Regression Analysis

Table 1 Multiple Linear Regression

Coefficients $^{\mathrm{a}}$

\begin{tabular}{|c|c|c|c|c|c|c|}
\hline \multirow{2}{*}{\multicolumn{2}{|c|}{ Model }} & \multicolumn{2}{|c|}{$\begin{array}{c}\text { Unstandardized } \\
\text { Coefficients }\end{array}$} & \multirow{2}{*}{$\begin{array}{c}\text { Standardized } \\
\text { Coefficients } \\
\text { Beta }\end{array}$} & \multirow[t]{2}{*}{$\mathrm{t}$} & \multirow[t]{2}{*}{ Sig. } \\
\hline & & B & Std. Error & & & \\
\hline \multirow{3}{*}{1} & (Constant) & 1.151 & .970 & & 1.187 & .237 \\
\hline & $\begin{array}{l}\text { Minimum } \\
\text { Investment } \\
\text { Capital }\end{array}$ & .256 & .095 & .213 & 2.694 & .008 \\
\hline & $\begin{array}{l}\text { Perception of } \\
\text { Risk }\end{array}$ & .373 & .058 & .508 & 6.411 & .000 \\
\hline
\end{tabular}

a. Dependent Variable: Student Investment Interest

Source: Primary data processed by SPSS 20.0. 2020

Based on the output results in table 1 above, it can be explained that the results of the regression equation $\mathrm{Y}=1.151+0.256+0.373$ means that without minimal investment capital and risk perception, student investment interest in the Faculty of Economics is 1,151. If the investment capital variable increases at least 1 point or high, it will cause an increase of 0.256 in the investment interest of students at the Faculty of Economics, University of Muhammadiyah Ponorogo. Meanwhile, if the risk perception increases by 1 point or good, it will cause an increase in student investment interest by 0.373 at the Faculty of Economics, University of Muhammadiyah Ponorogo. 


\section{Partial Hypothesis Test (t test)}

The partial significance test aims to determine whether there is an influence of the independent variables with the related variables either partially. The results of the analysis of the partial significance test ( $\mathrm{T}$ test) between the PKP independent variables on PU obtained the following results:

Table 2 Hypothesis Test ( $\mathrm{t}$ )

\begin{tabular}{|c|c|c|c|c|c|c|}
\hline \multirow{2}{*}{\multicolumn{2}{|c|}{ Model }} & \multicolumn{2}{|c|}{$\begin{array}{c}\text { Unstandardized } \\
\text { Coefficients } \\
\end{array}$} & \multirow{2}{*}{$\begin{array}{c}\begin{array}{c}\text { Standardized } \\
\text { Coefficients }\end{array} \\
\text { Beta }\end{array}$} & \multirow[t]{2}{*}{$\mathrm{t}$} & \multirow[t]{2}{*}{ Sig. } \\
\hline & & $\mathrm{B}$ & Std. Error & & & \\
\hline \multirow{3}{*}{1} & (Constant) & 1.151 & .970 & & 1.187 & .237 \\
\hline & $\begin{array}{l}\text { Minimum } \\
\text { Investment Capital }\end{array}$ & .256 & .095 & .213 & 2.694 & .008 \\
\hline & Perception of Risk & .373 & .058 & .508 & 6.411 & .000 \\
\hline
\end{tabular}

a. Dependent Variable: Student Investment Interest

Source: Primary data processed by SPSS 20.0. 2020

Based on the results of the SPSS 20.0 output in the table above, we can see the significance value of the coefficients of the minimum investment capital variable is 0.008 . This means that if we refer to the assumptions that have been determined in making decisions regarding the first hypothesis, we can conclude that the effect of minimal investment capital on student investment interest, the hypothesis is accepted by comparing the significance level value of $0.008<0.05$. or we can also see that the $t$ value of 2.694 is greater than the table value of 0.159. Furthermore, for the risk perception variable we can see the significance level value of 0.000 , meaning that the assumptions we have set for making decisions about the second hypothesis, we can conclude, namely the effect of risk perception on student investment interest, the hypothesis is accepted by comparing the significance level value of $0.000<0.05$. or we can also see from the $t$ value of 6,411 which is greater than T-table 0.159 . Thus, it can be explained that student investment interest at the Faculty of Economics, University of Muhammadiyah Ponorogo can be influenced by minimal investment capital and partial risk perceptions.

Furthermore, the researcher will perform a simultaneous test for the two independent variables on the dependent.

\section{Simultaneous Hypothesis Testing}

Table 3. Simultaneous Test

$\mathrm{ANOVA}^{\mathrm{a}}$

\begin{tabular}{|rl|r|r|r|r|r|}
\hline \multicolumn{2}{|l|}{ Model } & \multicolumn{1}{|c|}{$\begin{array}{c}\text { Sum of } \\
\text { Squares }\end{array}$} & df & \multicolumn{1}{c|}{$\begin{array}{c}\text { Mean } \\
\text { Square }\end{array}$} & F & Sig. \\
\hline \multirow{2}{*}{1} & Regression & 290.947 & 2 & 145.474 & 60.508 & $.000^{\mathrm{b}}$ \\
& Residual & 365.440 & 152 & 2.404 & & \\
& Total & 656.387 & 154 & & & \\
\hline
\end{tabular}

a. Dependent Variable: Student Investment Interest

b. Predictors: (Constant), Perception of Risk, Minimum Investment Capital

Source: Primary data processed by SPSS 20.0. 2020 
Based on the processed results in table 3 , it can be explained that the significance value shows that the significance value is $0.000<0.05$ or Fcount $60.058>$ Ftable $=3.06$ so that Ho is rejected. That is, there is an effect of minimal investment capital and risk perception on student investment interest simultaneously at the Faculty of Economics, University of Muhammadiyah Ponorogo and the third hypothesis proposed as an alternative (Ha) is accepted. Furthermore, the coefficient of determination test will be carried out.

\section{Conclusions And Suggestion \\ Conclusion}

Based on the results of the analysis and discussion in the previous chapter, the conclusions that can be drawn in this study are as follows:

1) There is a positive and significant influence between minimum investment capital on student investment interest at the Faculty of Economics, University of Muhammadiyah Ponorogo. These results indicate that to increase student investment interest, minimal investment capital can be constructed with indicators of initial capital determination, estimated investment funds, and investment returns. The consequence of these indicators will increase students' investment interest in deciding to invest in shares in the Indonesia Stock Exchange.

2) There is a positive and significant influence between risk perceptions on student investment interest at the Faculty of Economics, University of Muhammadiyah Ponorogo. These results indicate that to increase student investment interest, a minimum investment capital can be constructed with indicators of initial capital determination, investment fund estimation, and investment returns. The consequence of this indicator will increase students' investment interest in deciding to invest in shares in the Indonesia Stock Exchange.

3) There is a positive and significant effect of minimal investment capital and risk perception on student investment interest simultaneously at the Faculty of Economics, University of Muhammadiyah Ponorogo. These results indicate that to increase student investment interest, a minimum investment capital can be constructed with indicators of initial capital determination, investment fund estimation, and investment returns; and risk perception with risk level indicators to help minimize losses, the level of risk is proportional to the benefits that will be obtained and the high level of risk is an interesting challenge. The consequence of this indicator will increase students' investment interest in deciding to invest in shares in the Indonesia Stock Exchange. The contribution of the two variables contributed $44.3 \%$ and the remaining $55.7 \%$ was influenced by other variables not examined in the study.

\section{Suggestion}

Based on the discussion and conclusions that have been made in the previous chapter, the researcher is fully aware that in this study there are still weaknesses and weaknesses so that there needs to be improvement and attention for future studies. In addition, the author also provides several suggestions that need to be added so that further research can be better and maximized, namely as follows:

1) For students of the Faculty of Economics, University of Muhammadiyah Ponorogo, to increase investment interest in the form of desire, interest and confidence so that lecturers can make full contributions to increasing investment understanding, stimulus and education on the capital market (BEI) must be given continuously. In addition, minimal investment 
capital and risk perception need to be socialized to students so that it can increase student investment interest in the Indonesia Stock Exchange.

2) This research resulted from the use of an instrument in the form of a questionnaire based on the perception of the respondent's answer. This will cause problems if the perception of the respondent's answer is different from the real situation.

3) For researchers, this study does not consider other variables that may affect investment interest, only assuming minimal investment capital variables and risk perceptions that have potential possibilities.

4) For researchers, this study is only limited to the minimum investment capital variable, risk perception and investment interest so that for further research, other variables can be added such as educational intensity variables, technology intelligence and institutional policies. In addition, the results of this study are still far from perfect, so they require constructive suggestions for further research.

\section{REFERENCES}

Fahmi, Irham. 2015. “Manajemen Investasi”. Edisi 2. Jakarta: Salemba Empat

Ghozali, Imam. 2011. “Aplikasi Analisis Multivariate dengan program SPSS. Semarang: Badan Penerbit Universitas Diponegoro.

Jogiyanto, Hartono. (2010). “Teori Portofolio dan Analisis Investasi”. Yogyakarta: BPFE

Kusmawati. 2011. "Pengaruh Motivasi Terhadap Minat Berinvestasi Di Pasar Modal Dengan Pemahaman Investasi Dan Usia Sebagai Variabel Moderasi”. Jurnal Ekonomi Dan Informasi Akuntansi (JENIUS).Vol 2. No 2. Diakses pada tanggal 24 Oktober 2018

Malik, A.D. 2017. Analisa Faktor-Faktor yang Mempengaruhi Minat Masyarakat Berinvestasi di Pasar Modal Syariah melalui Bursa Galeri Investasi UISI. Jurnal Ekonomi dan Bisnis Islam. 3 (1): 61-84.

Marleni, Yela. 2017. "Pengaruh Pengetahuan Investasi, Manfaat Investasi, Persepsi Modal Minimal, Return dan Uang Saku Terhadap Minat Investasi Mahasiswa di Pasar Modal’. Skripsi. Jurusan Akuntansi: Politeknik Negeri Padang. Dikases pada tanggal 29 Oktober 2018.

Martalena \& Malinda, Maya. 2011. “Pengantar Pasar Modal”.Yogyakarta:ANDI

Merawati, Luh Komang. 2015. "Kemampuan Pelatihan Pasar Modal Memoderasi Pengaruh pengetahuan Investasi Dan Penghasilan Pada Minat Berinvestasi Mahasiswa”. Jurnal Ilmiah Akuntansi Dan Bisnis.Vol 10. No 2. Diakses pada tanggal 22 Oktober 2018.

Pajar, Rizki Chaerul. 2017. "Pengaruh Motivasi Investasi Dan Pengetahuan Investasi terhadap Minat investasi Di Pasar modal Pada mahasiswa FE UNY”. Skripsi. Fakultas Ekonomi:Universitas Negeri Yogyakarta. Diakses pada tanggal 10 Desember 2018. 
Raditya T, Daniel., dkk. (2014). "Pengaruh Modal Investasi Minimal Di BNI Sekuritas, Return, Dan Persepsi Terhadap Risiko Pada Minat Investasi Mahasiswa, Dengan Penghasilan Sebagai Variabel Moderasi”. E-Jurnal Ekonomi Dan Bisnis Universitas Udayana Volume 3.No 7. Diakses pada tanggal 22 Oktober 2018.

Rochmi, Muhammad N. 2018. "Jumlah Investor Saham Melonjak". https://beritagar.id/artikel/berita/jumlah-investor-saham-melonjak. Diakses pada 7 Januari 2019.

Rosyidah, S. M. dan Lestari, W. 2013. Religiusitas Persepsi Resiko dalam Pengambilan Keputusan Investasi pada Perspektif Gender. Journal Business and Banking. 3 (2): 189200.

Santoso, Slamet. 2015. "Penelitian Kuantitatif: Metode dan Langkah Pengolahan Data". Ponorogo: Umpo Press

Septyanto, Dihin. 2013. Faktor-Faktor yang Mempengaruhi investor Individu dalam Pengambilan Keputusan Investasi Sekuritas di Bursa Efek Indonesia (BEI). JurnalEkonomi. Vol.4, No.2

Sugiyono. 2017. “Metode Penelitian Kuantitatif, Kualitatif Dan Kombinasi (Mixed Methods)”. Bandung: Alfabeta

Sunariyah. 2011. “Pengantar Pasar Modal:Edisi Keenam”. UPP-STIM YKPN Yogyakarta.

Surat Keputusan Nomor: Kep-00071/BEI/11-2013. https://www.idx.co.id/Portals/0/StaticData /Regulation. Diakses pada tanggal 25 Januari 2019.

Susilowati, Yuliana. 2017. "Faktor-Faktor Yang Mempengaruhi Minat Mahasiswa Akuntansi Syariah Untuk Berinvestasi Di Pasar Modal Syariah”. Skripsi. Fakultas Ekonomi dan Bisnis Islam: Institut Agama Islam negeri Surakarta. Diakses pada tanggal 5 April 2018.

Tandio, Thimothius dan Widanaputra,A.A.G.P. 2016. "Pengaruh Pelatihan Pasar Modal, Return, Persepsi Risiko, Gender, Dan Kemajuan Teknologi Pada Minat Investasi Mahasiswa”. E-Jurnal Akuntansi Universitas Udayana. Vol 16, No 3. Diakses pada tanggal 22 Oktober 2018.

Winantyo, Aloysius G.H.. 2017. "Pengaruh Modal Minimal investasi, Pengetahuan Investasi, dan Preferensi Risiko Terhadap Minat Berinvestasi Mahasiswa”. Skripsi. Fakultas Ekonomi: Universitas Sanata Dharma. Diakses pada tanggal 5 April 2018.

Wulandari dkk. 2017. "Pengaruh Manfaat, Fasilitas, Persepsi Kemudahan, Modal, Return, Dan Perspsi Risiko Terhadap Minat Mahasiswa Untuk Berinvestasi Secara Online (Studi Pada Mahasiswa Jurusan AkuntansiProgram S1 Universitas Pendidikan Ganesha)”. EJurnal S1 Ak Universitas Pendidikan Ganesha. Volume 8, No 2. Diakses pada tanggal 10 Desember 2018. 
International Journal of Economics, Business and Accounting Research (IJEBAR)

Peer Reviewed - International Journal

Vol-4, Issue-3, 2020 (IJEBAR)

E-ISSN: 2614-1280 P-ISSN 2622-4771

http://jurnal.stie-aas.ac.id/index.php/IJEBAR 